\title{
The antigenic determinant of fibrin(ogen) measured with agglutination inhibition immunoassays
}

\author{
AYESHA MOLLA ${ }^{1}$, MARIA BENEDETTA DONATI ${ }^{2}$, AND J. VERMYLEN \\ From the Laboratory of Blood Coagulation, Medical Research Department, University of Leuven, Leuven, \\ Belgium
}

SYNOPSIS Agglutination inhibition immunoassays using antifibrinogen antiserum measure an antigenic determinant of fibrinogen which is located on the fragment $D$ parts of this molecule. This antigenic determinant of fragment $D$, in contrast to others, does not form an immune precipitate with antifibrinogen antiserum. Upon very extensive hydrolysis by plasmin, this antigenic determinant has a reduced affinity for its antibody.

\section{Nomenclature}

Fibrinogen possesses numerous antigenic determinants. An antiserum against human fibrinogen contains several types of antibodies; the best defined of these antibodies are anti-d and anti-e, which form precipitin lines with the antigenic determinants $d$ and $e$ of fragments $D$ and $E$ respectively (Seligmann and Marder, 1965). Fragments $D$ and $E$ are the large molecular weight derivatives of fibrinogen after extensive proteolytic degradation by plasmin (Nussenzweig and Seligmann, 1960; Nussenzweig, Seligmann, Pelmont, and Grabar, $1961)$. Recent work has shown that fragment $E$ is closely related to the central $\mathrm{N}$-terminal disulphide knot of fibrinogen (Kowalska-Loth, Gårdlund, Egberg, and Blombäck, 1973); one fragment E would be formed from one fibrinogen molecule. Fragment $D$ would be related to the peripheral C-terminal disulphide knots (Dudek-Wojciechowska, Kloczewiak, Latallo, and Kopeć, 1973); two fragments D would result from the plasmin cleavage of one fibrinogen molecule.

Agglutination inhibition immunoassays using antifibrinogen antiserum (AII) are widely used for the measurement of fibrinogen or fibrin derivatives in biological fluids. In this paper, fibrin(ogen)related antigen (FR-antigen) refers only to the antigenic determinant measured in AII (Merskey, Lalezari, and Johnson, 1971). The degradation of

\footnotetext{
${ }^{1}$ Research fellow of the Katholieke Universiteit te Leuven.

'Research Fellow of the Katholieke Universiteit te Leuven 1972/73. Present address: Laboratory for Haemostasis and Thrombosis Research, Mario Negri Institute, V. Eritrea 62-20157 Milano, Italy. Received for publication 21 February 1974.
}

human fibrinogen is commonly divided into three stages (Marder, Shulman, and Carroll, 1967); stage 3 has been defined as the absence of intermediate products $X$ and $Y$ and the presence of fragments $D$ and $E$. Stage 3 proteolysate is as reactive as unaltered fibrinogen in AII (Merskey, Kleiner, and Johnson, 1966; Marder, 1971b; Donati, Vermylen, and Verstraete, 1971b). A stage 4 can be defined as the stage at which a distinct (eight- or tenfold) drop of reactivity of the proteolysate in AII is found.

\section{The Process of Agglutination}

Red blood cells (Merskey et al, 1966) or latex particles (Allington, 1971) coated with fibrinogen are widely used to detect the presence of unbound antibody in mixtures of an unknown amount of FR-antigen and a fixed amount of antifibrinogen antiserum. It is still quite unclear which type of antibody in the antiserum is involved in agglutinating red cells or latex particles coated with fibrinogen, and therefore also which antigen of fibrinogen corresponds to FR-antigen. While all authors agree that the antigenic determinants of fragment $E$ are not measured with these methods, there is a marked discrepancy of opinion with regard to fragment $\mathbf{D}$. Marder (1971b) reported that fragment $D$ is nearly as reactive as fibrinogen, whereas our group (Donati, Molla, and Vermylen, 1971a) found that fragment D was inefficient in inhibiting haemagglutination; Feddersen and Gormsen (1971) also found that fragment $D$ inhibits very poorly haemagglutination in the tanned red cell haemagglutination inhibition immunoassay (TRCHII); Thuot and Larrieu (1971) 
stated that fragment $D$ is partly detected with the TRCHII. It therefore seems doubtful that antigenic determinants $d$ correspond to FR-antigen. Further evidence for this conclusion was provided by the observation that in a stage 4 proteolysate the concentration of antigenic determinants $d$ and $e$, measured by quantitative immunoprecipitation, was unchanged while the FR-antigen content appeared markedly reduced (Molla, Donati, Dotremont, and Vermylen, 1971). Furthermore, careful successive absorption of total antifibrinogen with purified fragments $D$ and $E$ resulted in an antiserum which no longer produced precipitin lines with fragment $D$ or E but was virtually as active as the total antifibrinogen in producing agglutination of tanned red cells coated with fibrinogen (Donati et al, 1971a). Finally, DEAE-cellulose chromatography seemed to allow partial separation of the FR-antigen from determinants d (Donati et al, 1971a).

Two possibilities were then considered: (1) the fibrinogen fragment carrying the FR-antigen is distinct from fragments $D$ and $E$; (2) fragment $D$ would carry, besides antigenic determinants $d$, the FR-antigen; the latter would have a reduced affinity for its antibody following very extensive fibrinogen proteolysis. In order to distinguish between both possibilities, several attempts to separate fragment $D$ from the fragment carrying the FRantigen were undertaken using different techniques. In addition, experiments were performed with absorbed fibrinogen antisera.

\section{Materials and Methods}

PREPARATION OF FIBRINOGENOLYSATE

Purified human fibrinogen and human plasmin were a gift of Kabi (Stockholm). Solutions of $5 \mathrm{mg}$ clottable protein per $\mathrm{ml} 0.2 \mathrm{M} \mathrm{Na} 2 \mathrm{HPO}_{4}-0.04 \mathrm{M}$ $\mathrm{NaCl}$ buffer, $\mathrm{pH} 8.0$, were incubated at $37^{\circ} \mathrm{C}$ with plasmin $(0.4$ CTA units $/ \mathrm{ml}$, final concentration) during eight hours for preparation of stage 3 and during 24 hours for preparation of stage 4 proteolysate. The $\mathrm{pH}$ of the digestion mixture remained constant during the proteolysis.

DEAE-cellulose chromatography

DEAE-cellulose chromatography of fibrinogenolysate was performed as previously described (Donati et al, 1971a).

\section{Sephadex G-75 gel chromatography}

Sephadex G-75 gel chromatography was performed at room temperature through a $2.5 \times 45 \mathrm{~cm}$ column (Pharmacia, Uppsala) eluted with the phosphate saline buffer pH 8.0 mentioned above. Six-ml samples were applied and 6-ml fractions collected with a LKB Ultrarac 2000-2 fraction collector. The light absorbence of the eluates was read at $280 \mathrm{~nm}$. FR-antigen and precipitating antigenic determinants in the eluates were detected with respectively the TRCHII (Merskey, Lalezari, and Johnson, 1969) and the radial immunodiffusion method (Mancini, Vaerman, Carbonara, and Heremans, 1964). The values obtained were transformed into $\mu \mathrm{g} / \mathrm{ml}$ fibrinogen-related material by simultaneous measurement of dilutions of a plasma standard with known fibrinogen content.

\section{Precipitation}

Ammonium sulphate precipitation was performed at room temperature by adding an increasing amount of fibrinogenolysate (from $0.1 \mathrm{ml}$ to $0.9 \mathrm{ml}$ ) to a decreasing amount of saturated ammonium $\omega$ sulphate (from $0.9 \mathrm{ml}$ to $0.1 \mathrm{ml}$ ), so that the total volume of the mixture always was $1 \mathrm{ml}$. The pre- cipitate obtained after at least one hour was dis- $\bar{c}$ solved in phosphate saline buffer and tested for light absorbence at $280 \mathrm{~nm}$ and for reactivity in the TRCHII.

\section{Electrophoresis}

Pevikon block electrophoresis was performed as described by Marder, James, and Sherry (1969a). One gram human fibrinogen (Kabi) was dissolved in $100 \mathrm{ml} 0.025 \mathrm{M}$ sodium citrate; after digestion during eight or 24 hours with plasmin, the fibrinogenolysate was concentrated by dialysis agains polyethylene glycol to a volume of 10 to $20 \mathrm{ml}$ and then dialysed twice against $0.05 \mathrm{M}$ veronal hydrochloric acid buffer pH 8.2. The sample then was applied with a syringe in a $10 \mathrm{~cm}$ long slit made at one extremity of the Pevikon block. Electrophoresis was carried out at room temperature with a constant circulation of cold water beneath the Pevikon block and at a constant current of $50 \mathrm{~mA}$ for 48 hours. Progression of the separation was checked every 12 hours by contact impressions with filter paper $\frac{7}{0}$ strips, which were then stained with Amido black.

At the end of the separation procedure the $N$ Pevikon block was cut: the portion containing the $N$ $D$ band in five segments of $1 \mathrm{~cm}$ width and that $N$ containing the narrower $\mathrm{E}$ band in three equal $\omega$ segments. Protein was eluted from each segment of Pevikon with $2 \% \mathrm{NaCl}$; the eluates were filtered $\stackrel{\varrho}{\subset}$ through Jenaer 3D5 glass funnels, were concentrated ${ }_{\infty}^{\infty}$ by dialysis against polyethylene glycol and centri- $\stackrel{+}{+}$ fuged at $25000 \mathrm{rpm}$ for 30 minutes in a Beckman $\frac{0}{\circ}$ model L2-65B ultracentrifuge to remove very small $\vec{D}$ particles of Pevikon. The concentration of $D$ and $E \frac{?}{\mathbb{Q}}$

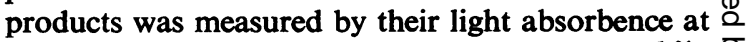
$280 \mathrm{~nm}$ based on extinction coefficients $\left(\mathrm{E}_{1}^{1} \%\right)$ 20.4 and 10.8 respectively (Marder, Shulman, and 8 
Carroll, 1969b). The purity of the fragments was checked by immunoelectrophoresis against antihuman fibrinogen antiserum (Hyland). Immunoelectrophoresis was performed as described by Scheidegger (1955). The segment of the Pevikon block between $\mathrm{D}$ and $\mathrm{E}$ was also eluted as described for the $D$ and $E$ areas. On each eluate of the Pevikon block the FR-antigen and precipitating antigenic determinants were quantitated respectively with the TRCHII and the radial immunodiffusion method.

\section{Results}

\section{ATTEMPTS TO SEPARATE FR-ANTIGEN FROM FRAGMENT D}

\section{Ammonium sulphate precipitation}

This revealed that $30 \%$ saturation of a stage 3 proteolysate with ammonium sulphate resulted in complete precipitation of FR-antigen.

The FR-antigen disappeared completely upon heating a stage 3 proteolysate at $56^{\circ} \mathrm{C}$ for 30 minutes.

\section{DEAE-cellulose chromatography of stage 3 proteolysates}

Following adsorption of a stage 3 fibrinogenolysate on DEAE-cellulose, three protein peaks are eluted by a salt gradient. The first does not contain material reacting immunologically and consists of small fragments previously termed A, B, and C by Nussenzweig and Seligmann (1960). The second and third peaks are constituted by fragments $D$ and $E$ respectively, as verified by immunoelectrophoresis.
Although in five out of seven experiments the elution position of the FR-antigen coincided with that of fragment $D$ (fig 1), in two experiments a dissociation of the elution position was observed. One of these has already been reported in detail (Donati et al, 1971a). The other experiment is illustrated in fig 2: whereas fragment $D$ is eluted as a fairly symmetrical peak (measured as optical density or as immunoprecipitating material), FR-antigen is eluted in two peaks; the second and highest peak coincides with the descending limb of the protein peak.

\section{Sephadex G-75 gel filtration of proteolysates}

Previous work from this laboratory had shown that, upon gel chromatography of a stage 3 proteolysate through $6 \%$ agarose, the elution position of FRantigen coincided with that of the largest fragments in the mixture (fragments D and E). However, this gel is not particularly suited for separation of molecules the size of D or E fragments. This experiment therefore was repeated using a column of Sephadex G-75. Two typical experiments are shown in figure 3. The left half represents a stage 3 proteolysate; a very sharp protein peak is found: the elution position of fibrinogen antigenic material, measured with the TRCHII or radial immunodiffusion, almost coincides; immunoelectrophoresis shows that fragments $\mathrm{D}$ and $\mathrm{E}$ are present in all fractions; the right half represents a stage 4 proteolysate; the protein peak is broader and slightly asymmetrical; the same is true for material reacting in the radial immunodiffusion test; immuno-

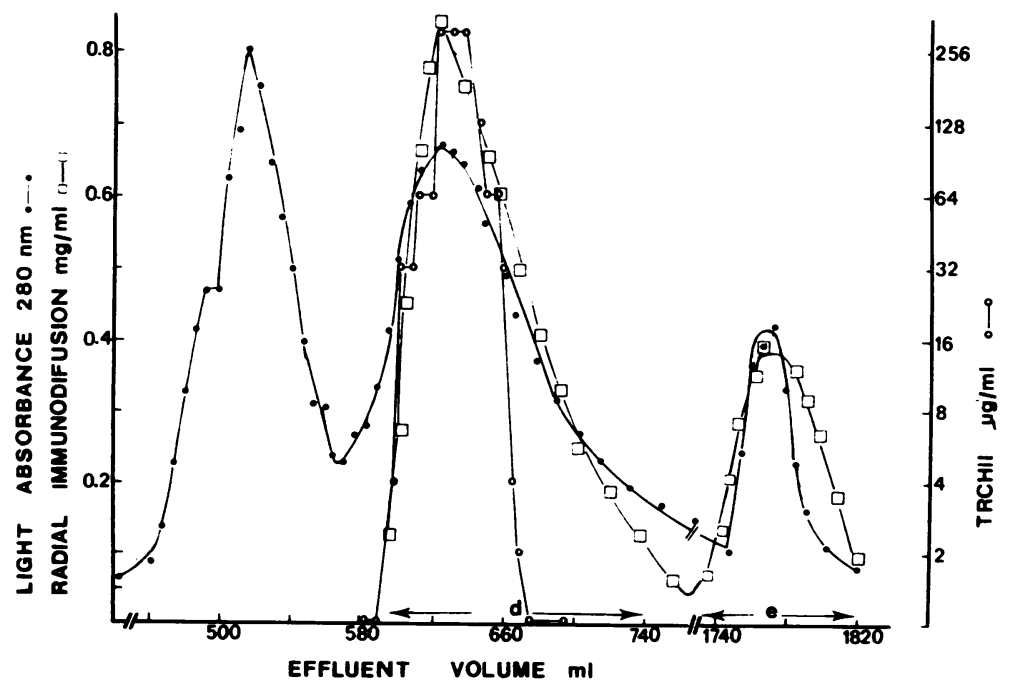

Fig 1 DEAE-cellulose chromatogram of a stage 3 fibrinogen proteolysate: elution of protein, of FR-antigen and of precipitating antigenic determinants detected and identified by radial immunodiffusion and immunoelectrophoresis respectively. 


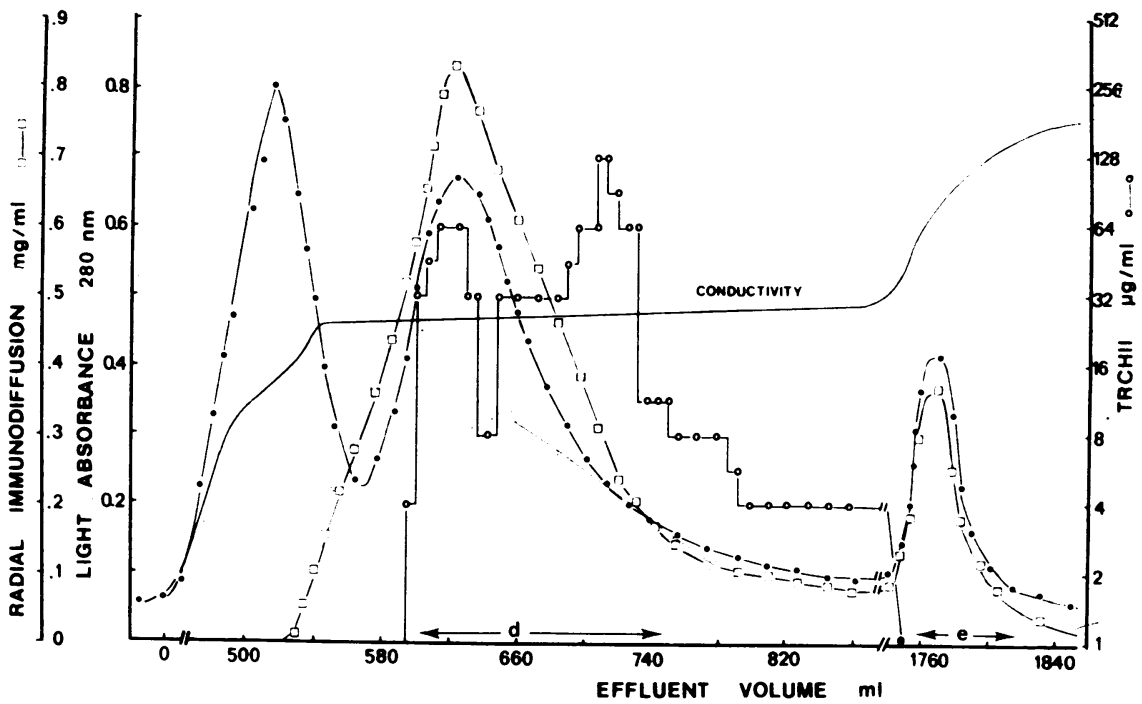

Fig 2 DEAE-cellulose chromatogram of a stage 3 fibrinogen proteolysate: elution of protein, of FR-antigen and of precipitating antigenic determinants detected and identified by radial immunodiffusion and immunoelectrophoresis, respectively.

electrophoresis shows that the trailing shoulder consists exclusively of fragment E; FR-antigen is located at the ascending limb of the protein peak. The figure does not show the elution position of the smaller fragments, which were non-reactive in the immunoassays.

Pevikon block electrophoresis

As shown in table I the distribution of FR-antigen and fragment $\mathrm{D}$ in the Pevikon block and their concentration were comparable after electrophoresis of a stage 3 digest. Very little FR-antigen was associated with fragment $E$. When a stage 4 digest was electrophoresced, the distribution of FR-antigen in the Pevikon block still coincided with that of fragment D. However, the concentration of FRantigen was much lower than that of fragment $D$.

Previous work from our laboratory had indicated
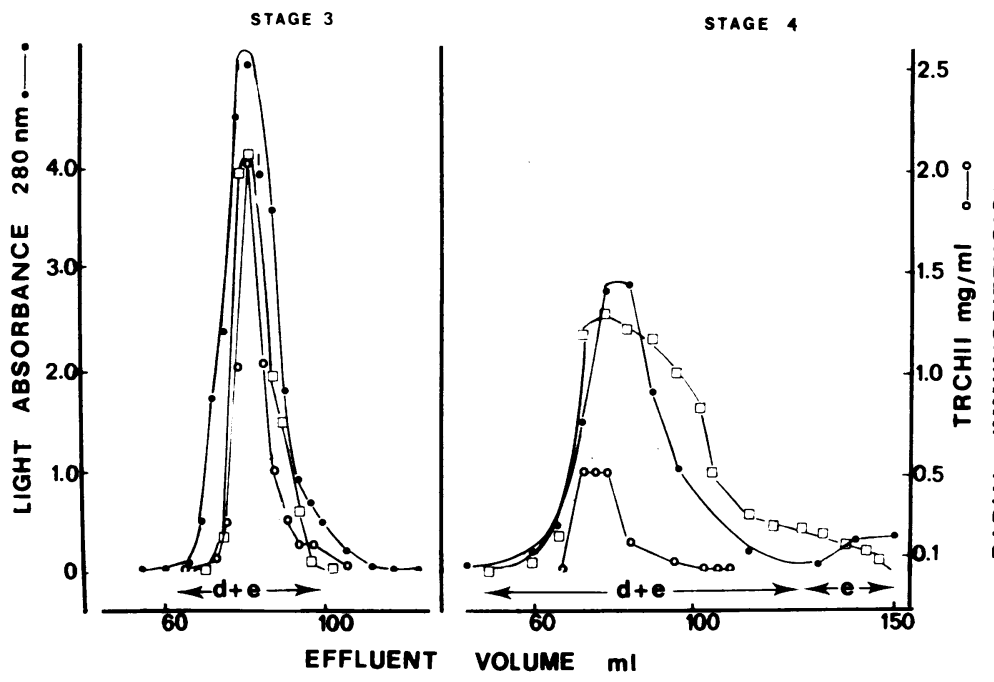

Fig 3 Sephadex $6-75$ gel

chromatogram of a stage 3 (left) and a stage 4 (right) fibrinogen proteolysate: elution of protein, of FR-antigen and of precipitating antigenic determinants detected and identified by radial immunodiffusion and immunoelectrophoresis, respectively. The void volume of the column was determined by the elution position of the leading peak of dextran blue and was $75 \mathrm{ml}$. The total volume was determined by the elution position of the oligopeptides in fibrinogenolysate and was $225 \mathrm{ml}$. 


\begin{tabular}{|c|c|c|c|c|c|c|c|c|c|}
\hline & \multicolumn{5}{|l|}{$D$} & \multirow[t]{2}{*}{$\begin{array}{l}\text { Region between } \\
D \text { and } E\end{array}$} & \multicolumn{3}{|l|}{$E$} \\
\hline & Segment I & Segment 2 & Segment 3 & Segment 4 & Segment 5 & & Segment 1 & Segment 2 & Segment 3 \\
\hline $\begin{array}{l}\text { Protein }(\mu \mathrm{g} / \mathrm{ml}) \\
\text { TRCHII }(\mu \mathrm{g} / \mathrm{ml}) \\
\text { Radial immunodiffusion }(\mu \mathrm{g} / \mathrm{ml})\end{array}$ & $\begin{array}{l}23 \cdot 5 \\
40 \cdot 0 \\
60 \cdot 0\end{array}$ & $\begin{array}{l}23 \cdot 8 \\
40 \cdot 3 \\
68 \cdot 3\end{array}$ & $\begin{array}{l}25 \cdot 0 \\
45 \cdot 0 \\
70 \cdot 1\end{array}$ & $\begin{array}{l}20 \cdot 0 \\
30 \cdot 0 \\
51 \cdot 0\end{array}$ & $\begin{array}{r}10 \cdot 0 \\
8 \cdot 0 \\
3 \cdot 0\end{array}$ & $\begin{array}{l}0.5 \\
3.0\end{array}$ & $\begin{array}{r}45 \cdot 3 \\
1 \cdot 5 \\
39 \cdot 0\end{array}$ & $\begin{array}{r}40 \cdot 0 \\
1 \cdot 0 \\
32 \cdot 8\end{array}$ & $\begin{array}{r}10 \cdot 0 \\
3 \cdot 0 \\
5 \cdot 3\end{array}$ \\
\hline
\end{tabular}

Table I Distribution in a Pevikon block of protein, of FR-antigen, and of precipitating antigenic determinants after electrophoresis of a stage 3 proteolysate

\begin{tabular}{|c|c|c|c|c|c|c|c|}
\hline $\begin{array}{l}\text { Dilution of } \\
\text { Test Sample }\end{array}$ & $\begin{array}{l}\text { D Alone } \\
(644 \mathrm{\mu g} / \mathrm{ml})\end{array}$ & $\begin{array}{l}5 \text { Parts } D \\
I \text { Part } E\end{array}$ & $\begin{array}{l}4 \text { Parts } D \\
2 \text { Parts } E\end{array}$ & $\begin{array}{l}3 \text { Parts } D \\
3 \text { Parts } E\end{array}$ & $\begin{array}{l}2 \text { Parts } D \\
4 \text { Parts } E\end{array}$ & $\begin{array}{l}1 \text { Part } D \\
5 \text { Parts } E\end{array}$ & $\begin{array}{l}\text { E Alone } \\
(847 \mathrm{\mu g} / \mathrm{ml})\end{array}$ \\
\hline $1 / 1$ & - & - & - & - & - & - & + \\
\hline $1 / 2$ & - & - & - & - & - & - & + \\
\hline $1 / 4$ & - & - & - & - & - & - & + \\
\hline $1 / 4$ & - & - & - & - & - & - & + \\
\hline $1 / 16$ & - & - & - & - & - & - & + \\
\hline $1 / 32$ & - & - & - & - & - & - & + \\
\hline $1 / 64$ & - & - & - & + & + & + & + \\
\hline $1 / 128$ & - & - & + & + & + & + & + \\
\hline $1 / 256$ & - & - & + & + & + & + & + \\
\hline $1 / 512$ & - & + & + & + & + & + & + \\
\hline $1 / 1024$ & + & + & + & + & + & + & + \\
\hline
\end{tabular}

Table II Haemagglutination inhibition by $D$ and $E$ fragments purified from a stage 3 proteolysate and following recombination in different proportions

- no agglutination; + agglutination.

that recombination in different proportions of fragments $D$ and $E$, isolated by DEAE-cellulose chromatography from a stage 4 digest, did not enhance the weak haemagglutination inhibiting activity of fragment $D$. An identical conclusion was reached when fragments $D$ and $E$, isolated by Pevikon block electrophoresis from a stage 3 digest, were recombined in different proportions (table II).

\section{ABSORPTION OF THE FIBRINOGEN \\ ANTISERUM WITH FRAGMENT D \\ Fragment D was isolated from a stage 3 fibrinogen proteolysate by Pevikon block electrophoresis. A solution of $5.36 \mathrm{mg} / \mathrm{ml}$ fragment $D$ was made. By adding $0.05 \mathrm{ml}$ of this fragment $\mathrm{D}$ solution to $1.55 \mathrm{ml}$ antifibrinogen Hyland (these proportions obtained by Ouchterlony titration of the equivalence points) and allowing the precipitate to form for 24 hours at $4^{\circ} \mathrm{C}$, an antiserum was obtained which did not form precipitin lines with fragment $D$ but was as effective as the unabsorbed antiserum for agglutin- ating red cells coated with human fibrinogen. Ag- glutination by the antiserum could, however, be abolished by mixing $0.8 \mathrm{ml}$ of the fragment $D$ solution with $0.2 \mathrm{ml}$ antifibrinogen.}

\section{Discussion}

Fragment $\mathrm{D}$ is thermolabile (Nussenzweig et al, 1961) and precipitated by saturation of the solution to $30 \%$ with ammonium sulphate (Marder, 1971a). Heat denaturation, ammonium sulphate precipitation, gel filtration, preparative Pevikon block electrophoresis, and most experiments using DEAE-cellulose chromatography did not allow separation of the FR-antigen from fragment $D$. By contrast, most of these experimental procedures clearly established that the fragment carrying FR-antigen is unrelated to the other fragments present in a stage 3 or stage 4 proteolysate of fibrinogen. The results of the absorption experiments indicate that antifibrinogen antiserum contains two types of antibodies against fragment $D$ : one type forms immune precipitates with fragment $D$ (antibodies against antigenic determinants d); the second type is responsible for agglutination of red cells coated with fibrinogen, does not form immune precipitates with fragment $D$ but can be neutralized by fragment $D$. The lack of precipitate formation suggests that fragment $D$ carries a single antigenic determinant (antigenic determinant $\mathrm{d}^{2}$; FR-antigen) reacting with that second type of antibody; fragment $D$, in contrast to fibrinogen itself, would thus be asymmetrical.

The difference in reactivity in the TRCHII of fragment $D$ from a stage 3 or a stage 4 proteolysate indicates that, upon extensive proteolytic degradation of fragment $D$ by plasmin, antigenic determinant $d^{2}$ would have a reduced affinity for its antibody. If one accepts that different authors 
have studied fragment $D$ at different stages of degradation, the discrepancy of opinion with regard to the sensitivity of AII to fragment D, as summarized in the introduction, can readily be explained. In the two DEAE-cellulose experiments, in which the elution position of the fragment carrying FR-antigen did not coincide completely with that of fragment $\mathrm{D}$, one can assume the presence of a mixture of extensively and less extensively degraded fragment $\mathrm{D}$, only the latter reacting well in the TRCHII.

The existence of several degrees of degradation of fragment $\mathrm{D}$ has already been suggested: Latallo, Dudek, and Kloczewiak (1971) and Molla et al, (1971) have reported that upon very extensive plasmic degradation of fibrinogen, the anodic mobility of fragment D increases; Pizzo, Schwartz, Hill, and McKee (1972) have indicated that the subtypes of $\mathrm{D}$ differ with regard to the length of the $\gamma$-chain; shortening of this chain could then perhaps reduce the affinity of antigenic determinant $\mathrm{d}^{2}$ for its antibody. Gaffney (1972) made a distinction between $\mathrm{Dg}$ and $\mathrm{Dp}$, the $\gamma$-chain of the latter being further degraded. Moreover, he reported that the fragment $\mathrm{D}$ found in plasma and urine has a lower anodic mobility than fragment $\mathrm{D}$ produced by the prolonged enzymatic digestion of fibrinogen. The less extensive degradation of fragment $D$ formed in vivo could explain the very close correlation between the results of the TRCHII and the radial immunodiffusion technique, when these methods are used for the study of urine samples (Molla et al, 1971). The antigenic determinant $\mathrm{d}^{2}$ would seem to be distinct from the specific antigenic determinant of the D:E complex (Plow and Edgington, 1972) since fragment $D$, isolated from a stage 3 digest and devoid of detectable $\mathrm{E}$, inhibits effectively agglutination by antihuman fibrinogen antibody (Marder, 1971; this study), and since recombination of fragments $D$ and $E$ does not increase the amount of FR-antigen measured (Donati et al, 1971a; this study). The antigenic determinant $\mathrm{d}^{2}$ is clearly distinct from the stable cleavage associated neo-antigen, present in fragment D (Plow and Edgington, 1973); indeed, anti- $\mathrm{d}^{2}$ antibody is present in antihuman fibrinogen antiserum, is not absorbed with extensively degraded fragment $D$ but readily absorbed by unaltered fibrinogen.

In conclusion we propose that, for the designation of the antigenic determinant of fibrinogen measured in AII, the vague but until now useful term 'FRantigen' could be replaced by the more specific term 'fibrinogen antigen $\mathrm{d}^{2}$ '.

This work was supported by grant no. 1216 of the NWGO, Belgium.
References

Allington, M. J. (1971). Detection of fibrin(ogen) degradation products $\rightrightarrows$ by a latex clumping method. Scand. J. Haemat., Suppl., 13, $115-119$.

Donati, M. B., Molla, A., and Vermylen, J. (1971a). The tanned red cell hemagglutination inhibition immunoassay and purified $\overline{\bar{\sigma}}$ fibrinogen degradation products. Scand. J. Haemat., Suppl., $\overline{\bar{\sigma}}$ 13, 91-99.

Donati, M. B., Vermylen, J., and Verstraete, M. (1971b). The staphylococcal clumping test for detection of fibrinogen-like material. صి
Scand. J. Haemat., Suppl., 13, 137-143.

Dudek-Wojciechowska, G. A., Kloczewiak, M., Latallo, Z. S., and $\overrightarrow{0}$ Kopeć, M. (1973). Characterisation of large fragments rich in $\bigcirc$ disulphide bridges from CNBr-treated products of exhaustive $=$ proteolysis of fibrinogen by plasmin. Biochim. biophys. Acta $\vec{\omega}$ (Amst.), 295, 536-542.

Feddersen, C., and Gormsen, J. (1971). Plasmin digestion of stabilized and non-stabilized fibrin illustrated by immunoelectrophoresis $O$ and haemagglutination inhibition immunoassays. Scand. J. N
Haemat., 8, 461-469.

Gaffney, P. J. (1973). Subunit relationships between fibrinogen and fibrin degradation products. Thrombosis Res., 2, 201-218.

Kowalska-Loth, B., Gårdlund, B., Egberg, N., and Blombäck, B. (1973). Plasmic degradation products of human fibrinogen. II. 0 Chemical and immunological relation between fragment $\mathrm{E}$ 금 and N-DSK. Thrombosis Res., 2, 423-450.

Latallo, Z. S., Dudek, G. A., and Kloczewiak, M. (1971). A possible $\subset$ relation between the location of $D$ and $E$ fragments and of the $\subseteq$ N-terminal disulphide knots in fibrinogen molecule. Scand. J. Haemat., Suppl., 13, 37-41.

Mancini, G., Vaerman, J. P., Carbonara, A. O., and Heremans, J. F. $\overrightarrow{0}$ (1964). A single radial diffusion method for the immunological quantitation of proteins. Protides biol. Fluids, 11, 370-373.

Marder, V. J. (1971a). Identification and purification of fibrinogen $\square$ degradation products produced by plasmin: considerations on the structure of fibrinogen. Scand. J. Haemat., Suppl., 13, 2136.

Marder, V. J. (1971b). Discussion. Scand. J. Haemat., Suppl., 13, p. 121.

Marder, V. J., James, H. L., and Sherry, S. (1969a). The purification $\stackrel{\mathcal{D}}{\mathrm{Q}}$ of fibrinogen degradation products by Pevikon block electro- $\Rightarrow$ phoresis. Thrombos. Diathes. haemorrh. (Stuttg.), 22, 234-239. 윽

Marder, V. J., Shulman, N. R., and Carroll, W. R. (1967). The 3 importance of intermediate degradation products of fibrinogen $\widetilde{T}$ in fibrinolytic hemorrhage. Trans. Ass. Amer. Phycns., 80, 156-167.

Marder, V. J., Shulman, N. R., and Carroll, W. R. (1969b). High molecular weight derivatives of human fibrinogen produced by $\frac{\Omega}{0}$ plasmin. I. Physicochemical and immunological characterization. J. biol. Chem., 244, 2111-2119.

Merskey, C., Kleiner, G. J., and Johnson, A. J. (1966). Quantitative estimation of split products of fibrinogen in human serum, relation to diagnosis and treatment. Blood, 28, 1-18.

Merskey, C., Lalezari, P., and Johnson, A. J. (1969). A rapid, simple, sensitive method for measuring fibrinolytic split products in 윽 human serum. Proc. Soc. exp. Biol. (N.Y.), 131, 871-875.

Merskey, C., Lalezari, P., and Johnson, A. J. (1971). Tanned red $\frac{D}{O}$ cell hemagglutination inhibition immunoassay for fibrinogen- 을. fibrin-related antigen ('fibrinolytic degradation products') in human serum. Scand. J. Haemat., Suppl., 13, 83-85.

Molla, A., Donati, M. B., Dotremont, G., and Vermylen, J. (1971). Comparison of the tanned red cell hemagglutination inhibition $\mathrm{N}$ immuno-assay and radial immunodiffusion for the quantitation $\mathrm{N}$ of fibrinogen-related antigen in urine concentrates. Scand. J. $\omega$ Haemat., Suppl., 13, 225-228.

Nussenzweig, V., and Seligmann, M. (1960). Analyse, par des méthodes immunochimiques, de la dégradation par la plasmine du吕 fibrinogène humain et de la fibrine, à differents stades. Rev. $\frac{\mathrm{C}}{\mathbb{C}}$ Hémat., 15, 451-466.

Nussenzweig, V., Seligmann, M., Pelmont, J., and Grabar, P. (1961). Les produits de dégradation du fibrinogène humain par la. plasmine. I. Séparation et propiétés physico-chimiques. Ann. Inst. Pasteur, 100, 377-389.

Pizzo, S. V., Schwartz, M. L., Hill, R. L., and McKee, P. A. (1972) 吕 The effect of plasmin on the subunit structure of human fibrinogen. J. biol. Chem., 247, 636-645.

Plow, E. F., and Edgington, T. S. (1972). The D:E complex: a native conformational component of the fibrinogen molecule. Thrombosis Res., 1, 605-618. 
Plow, E.F., and Edgington, T. S. (1973). Immunobiology of fibrinogen: emergence of neoantigenic expressions during physiologic cleavage in vitro and in vivo. J. clin. Invest., 52, 273-282.

Scheidegger, J. J. (1955). Une micro-méthode de l'immunoeléctrophorèse. Int. Arch. Allergy, 7, 103-110.

Seligmann, M., and Marder, V. J. (1965). Application des techniques immuno-chimiques à l'étude du fibrinogène et de ses produits de dégradation par la plasmine. Nouv. Rev. franc. Hémat., 5, 345-354

Thuot, C., and Larrieu, M. J. (1971). Fibrinogen degradation products: a critical study of two assay methods. Rev. europ. Etud. clin. Biol., 16, 27-34. 